Research Journal of Applied Sciences 13 (1): 5-9, 2018

ISSN: $1815-932 \mathrm{X}$

(C) Medwell Journals, 2018

\title{
Agricultural Extension Services and Food Production Among Esan Rural Women Farmers in Edo State, Nigeria
}

\author{
M.I. Ozoya, P.A. Edewor, T.C. Iruonagbe and I.A. Chiazor \\ Department of Sociology, Covenant University, Ota, Ogun State, Nigeria
}

\begin{abstract}
The need to boost food production has been on the front burner in recent time. One avenue through which farmers in many contexts have been assisted to increase their food production capacity is through their access to agricultural extension services. Data relating to the extent to which Esan rural women farmers have benefited from this remarkable practice remains scarce in literature. This study was conducted to fill that gap. Primary data were collected through quantitative and qualitative methods. Respondents for the quantitative data consisted of 457 rural women farmers. Qualitative data was conducted with the use of In-Depth Interview (IDI) and Focused Group Discussions (FGDs). Quantitative data were analyzed with the use of descriptive statistics while content analysis was employed for qualitative data. Findings showed that only $0.2 \%$ of the respondents had accessed agricultural extension services in the study area. It was concluded that Esan rural women farmers lack access to agricultural extension services. Some recommendations were made based on findings.
\end{abstract}

Key words: Agricultural extension services, rural women farmers, Esan, Edo State, Nigeria, food production

\section{INTRODUCTION}

Access to credit land, advanced technology, agricultural education and credit facilities are vital towards ensuring food security (Chiazor et al., 2016). Agricultural extension services are known to be important in serving as a cost-effective method of boosting the productivity and income of farmers (Adesiji et al., 2013; Tayo et al., 2016). According to the report of Global forum for Rural Advisory Service (GFRAS, 2012), the following facts describe the state of extension services globally:

- Investment in extension yields $80 \%$ annual rates of return $(40-60 \%$ is the norm)

- Educating farmers can help to double crop yields

- In 1988, US\$6 billion was invested in extension globally

- In 2009, US\$582 million of World Bank funding went to research and extension about $10 \%$ of the overall spent on agriculture

- Around $43 \%$ of rural workers are women but only $5 \%$ of women have access to extension services

It has been noted that extension services enable farmers to adopt current innovations, boost food production sometimes as high as $13-500 \%$ and protect the environment. However, efforts at obtaining data on the effects of extension trainings pose a great challenge due to the divergence on farmer's access to extension services across various communities (FAO, 2003). Nevertheless, positive impacts have been recorded in certain countries as more farmers access extension services. Such positive outcomes have been observed in China, Vietnam and Indonesia. In China and Vietnam, it is estimated that there is 1 extension worker per 280 farm households, Indonesia reports that each extension worker covers about 2.8 villages. Furthermore, a programme with Cacao farmers in Peru has been reported to have resulted in productivity increase from $340-600 \mathrm{~kg} / \mathrm{ha}$ in 3 years (GFRAS, 2012).

Though, women play a central role in agriculture across Africa including Nigeria, most of them are often bypassed in agricultural extension trainings. Adesiji et al. (2013) attribute the prevailing negligence of women farmers by extension agents to women's "limited control over assets and decisions and systemic biases that are evident in agricultural institution throughout Africa and much of the world". A major asset over which women lack control and ownership is land. IFAD notes that, a significant portion of the income of the rural poor comes from farming, the report therefore recommended that democratizing access to and control over land and water resources is crucial for empowering women. It must be mentioned that extension services are often tailored

Corresponding Author: M.I. Ozoya, Department of Sociology, Covenant University, Ota, Ogun State, Nigeria 
according to the type of crop mostly cultivated in an area and the type of crop cultivated is determined by source of land (Iruonagbe, 2010).

Study objective: This study conducted to determine the extent through which Esan rural women farmers benefit from agricultural extension services.

Literature review: The emergence of agricultural extension services is traceable to the colonial era in Nigeria. It started with the promotion of export crops such as cocoa, rubber, timber and cotton. It is not, therefore, surprising that this has not been successfully extended to advance the production of food crops. Extension services have undergone several approaches in Nigeria. These include The Special Commodity Service, Farm Settlement Scheme, River Basin Development Authority, The National Accelerated Food Programme and The Operation Feed the Nation. In 1986, the training and visit extension system was introduced. However, these have failed to produce expected results (Aigbokhan, 2001).

Women-in-Agriculture (WIA) in Nigeria is a branch of the Agricultural Development Projects (ADP). Report has shown that they have made important progress in different states of the federation by incorporating gender in agricultural extension, modifying the ADP system midstream to provide for women farmers through the creation of programmes in the Department of Extension Services of the affected states with a gender focus (Odurukwe et al., 2006).

The WIA programme designed avenues to improve agricultural extension services for women. Such avenues involve the retraining of existing agents in agriculture and extension methodologies as well as emphasizing women's activities. In addition, the WIA programme is organized in such a manner that extension services in every state in Nigeria have female extension workers at all levels of operation from state capital to the villages (Adesiji et al., 2013). This programme was established not essentially for soil cultivation but mainly to mobilize women in gender specific activities which include post-harvest activities like processing, utilization, storage and marketing of agricultural products. The main services of WIA continue to be organizing women into groups and assisting them start group-farms. It is through, these groups that WIA extension agents transfer required technology to be adopted by the women. However, the WIA programme sets much importance on off-farm undertakings of the women and the concentration has mainly been on the transfer of home economics technology (Adesiji et al., 2013; Odurukwe et al.,
2006), according to the study carried out by Odurukwe et al. (2006), on the impacts of the Women-in-Agriculture (WIA) extension programme on women's lives in Imo state, positive result was recorded from the adoption of this programme by women as these women are now able to improve in such areas as family food security and increased financial contribution to household needs. Impact in children's education has also recorded positive response. It, however, shows that the impact was more on rural women than their urban counterpart.

Some factors have been identified as limiting the ability of extension service agents from extending agricultural trainings to farmers. Adesiji et al. (2013) identified the following constraints in the study of Southwest Nigeria:

- Poor state of road infrastructure

- The preference of male extension workers to work with male farmers

- Non-availability of suitable means of transportation

- Irregular supplies of extension materials

Study area: Esan West is one of the five local government areas that comprise of the area known as Esan. It is located in Edo State, Southern part of Nigeria. Farming is the dominant occupation in the area, especially, among rural women who mainly cultivate cassava (Ozoya, 2008). Different parts of Nigeria have different crops that flourish due to the difference in rainfall and soil texture. The Northern part is known for such crops as groundnut, wheat, millet, sorghum, potatoes, tomatoes, onions and carrot. The concept of 'groundnut pyramid' still continues to exist in the literature even though they have disappeared. The Eastern part is known for palm oil, palm wine, plantain, banana and plenty of sea-foods. The western part of Nigeria is known for cocoa, oranges, yam and cassava. The predominance of cocoa in the west stimulated the construction of the 'Cocoa House' located in Ibadan, Oyo State. Pitiably, this edifice is highly underutilized today.

The Southern division of Nigeria has a favourable soil for the cultivation of rubber, cassava, cocoa, cotton, melons, yam, rice, oranges, oil palm, beans, pepper and fluted pumpkin (Ojo, 2001). The Niger Delta located in this part which would have contributed immensely to the availability of sea-food has been incapacitated by the activities of petroleum and gas industries resulting from oil spillage. Finally, the middle belt has abundance of rice, maize, yam, garbage, onions and sea-foods. Among these crops, cassava has become remarkable deriving 
from its transformation from a food crop to a cash crop. This was instigated by the breakthrough made by IITA in the 1970's (Ojo, 2001; Daramola, 2005; Okoduwa, 2007).

\section{MATERIALS AND METHODS}

Method of data collection and analysis: Both quantitative and qualitative data were utilized in this study. Quantitative data were obtained from 457 respondents with the use of a structured questionnaire. The respondents were rural women farmers between the age of 20 and 69 years. The copies of questionnaire were administered to the respondents on a face-to-face approach due to the high level of illiteracy found among them. The accidental sampling technique was adopted in the selection of respondents. Qualitative data were obtained through In-Depth Interview (IDI) and Focused Group Discussions (FGDs). IDI was conducted with the Local Government Officials while FGDs were conducted with the rural women farmers. Two relevant persons that were selected for the IDI were; Head of the Extension Department in the local government area and a senior officer in the office of the local government chairman. Quantitative data were analyzed with the use of descriptive statistics while content analysis was employed for qualitative data.

\section{RESULTS AND DISCUSSION}

Socio-demographic data: The mean age of the women was found to be 48 years. Most of the respondents (45.1\%) were found to reside in Ekpoma, the capital of the local government area, from where they proceed to engage farming in the villages. Primary education was found to be the dominant highest level of education attained by the respondents and this was reported by $44 \%$ of the respondents. The marital status of respondents should that most of them $(63.5 \%)$ were married. In terms of religion, 95.2 reported that they were Christians.

Table 1 reveals that agricultural extension services are not available to most of the respondents in the study area as only 1 respondent $(0.2 \%)$ was found to have ever attended an agricultural training. This implies that 456 respondents $(99.8 \%$ ) have not participated in any agricultural extension services. Reasons were sought from other respondents on why they have not attended any agricultural extension training. They all unanimously reported that their non-attendance has been due to the absence of any training organized for them in their
Table 1: Access to agricultural extension services and impact on food production

\begin{tabular}{lrr}
\hline Items & No. of respondents & Percentage \\
\hline $\begin{array}{l}\text { Have you attended any agricultural } \\
\text { extension training? }\end{array}$ & 1 & \\
Yes & 456 & 0.2 \\
No & 457 & 100 \\
Total & & \\
If no, why not? & 456 & 100 \\
$\begin{array}{l}\text { None organized in the community } \\
\text { If yes, where }\end{array}$ & 1 & 100 \\
In the L.G.A. & & \\
$\begin{array}{l}\text { When the training was organized? } \\
\text { Less than a year ago }\end{array}$ & 1 & 100 \\
The agricultural extension training focus & & \\
How to use chemicals & 1 & 100 \\
Does the training hold often? & & \\
Yes & 0 & 0 \\
$\begin{array}{l}\text { No } \\
\text { Total }\end{array}$ & 1 & 100 \\
Has the training increased your food & 1 & 100 \\
production? & & \\
Yes & & \\
No & & \\
Total & 1 & 100 \\
\hline
\end{tabular}

communities. By logical reasoning, this position can be said to be true due to the collective structure of rural areas. As such if any training was organized for any female farmers in the communities, news will be passed around to inform others. It can be deduced, therefore, that no training was organized in the community. The participants in the interviews and focus group discussions unanimously asserted that agricultural extension services were completely absent in their farming occupation.

The only respondent who attended the training reported that the training held at the local government headquarters but that, it does not hold often and that the focus of the training was on how to apply chemicals on plants. With respect to increase in food production as a result of attendance of an agricultural training, the respondent reported that there was no increase in food production after the training as she was yet to harvest the crops that she applied the chemicals on. Consequently, it cannot be said that agricultural extension services have impacted positively on food production capacity of rural women in Esan West local government area.

Responses from the focus group discussants and in-depth interviews revealed that most respondents who reported to have been trained received such trainings from their husbands and other family members, none was found to have been trained by extension service officials. This confirms the findings of existing studies that most rural women obtain farming information from their 
husbands and other family members which a sign of disempowerment (Ozoya et al., 2016a, b; Adesiji et al., 2013; Aina, 2012; Edewor, 2002). One of the participants reported as follows:

We have heard from some people that they are teaching somefarmers how to cultivate cassava that will bring much yield and take shorter period to harvest. But on this side of the nation, we have not seen such improved cassava or anyone to teach us how to cultivate them. We have even heard that some farmers can call extension service agents through their telephones to get information. But that is not the case here

Response from the in-depth interview with the Head of the Agricultural Department in Esan West local government Area supports the foregoing position:

It is true that there is an Agricultural Department in the local government headquarter which is supposed to be involved in training farmers on the most efficient methods to boost their yield and providing them with current farm technologies but there is huge deficiency in funding the activities of that department. We have qualified staff to do what we are supposed to do. You see the ruling party also determines the flow of resources to different areas within the state. We are under the Peoples Democratic Party (PDP) here in the local government whereas it is All Progressive Congress (APC) that is the ruling party at the state level

It can be deduced from qualitative data that political party affiliation can affect the resources for agricultural extension services.

\section{CONCLUSION}

The study has shown that constraints of extension workers impact negatively on rural women farmer's capability for food production. They, therefore, serve as a call for necessary action as extension services are to be extended to rural women farmers adequately. There is need to rehabilitate the physical infrastructure such as roads; recruit and train more women extension service providers; make suitable transportation means available; and ensure regular supply of extension materials to extension agents by the authorities responsible for that function. Revisiting the local government autonomy bill might be helpful in this regard. This is with the hope that, it will make resources available in every local government area irrespective of the political party at the state level. It is expected that direct allocation from the Federal government to the local government will enable grassroots developmental projects including agriculture. Finally, demonstration sites should be established for extension agents in the local government for easy access to the women farmers.

\section{REFERENCES}

Adesiji, G.B., F.B. Kehinde and K.F. Omotesho, 2013. Women farmers' attitudes towards agricultural extension services in southwest Nigeria. Nigerian J. Rural Extension Dev., 7: 23-28.

Aigbokhan, B.E.N.E., 2001. Resuscitating agricultural production (Cocoa, Cotton, Groundnuts, Palm oil, Rubber, etc.) for exports. Proceedings of the 10th Annual Conference on Zonal Research Units of the Central Bank of Nigeria (CBN), June 4-8, 2001, Central Bank of Nigeria, Owerri, Nigeria, pp: $1-24$.

Aina, O.I., 2012. Two Halves Make a Whole: Gender at the Crossroads of the Nigerian Development Agenda. Obafemi Awolowo University, Ife, Nigeria, Pages: 126.

Chiazor, I.A., M.E. Egharevba and M.I. Ozoya, 2016. Widening inequality and poverty in the developing world-micro-financing as a viable solution. Soc. Sci., 11: 3286-3293.

Daramola, B., 2005. Government policies and competitiveness of nigerian rice economy. Proceedings of the Workshop on Rice Policy and Food Security in Sub-Saharan Africa, Nov. 7-9, WARDA, Cotonou, Republic of Benin, pp: 1-18.

Edewor, P.A., 2002. African Economic Structure. In: The Social Structure of Contemporary African Societies, Shoremi, O.M. and A.A. Oyekunle (Eds.). Kraft Books, Ibadan, Nigeria, pp: 93-104.

FAO., 2003. The uplift and empowerment of rural women (Farmer's wife). Food and Agriculture Organization, Rome, Italy.

GFRAS., 2012. Fact sheet on extension services. Global Forum for Rural Advisory Services, Ingham, Queensland, Australia.

Iruonagbe, T.C., 2010. Gender equity and food security. Afr. Renaissance, 7: 89-110. 
Odurukwe, S.N., E.C. Matthews-Njoku and N. Ejiogu-Okereke, 2006. Impacts of the Women-In-Agriculture (WIA) extension programme on women's lives: Implications for subsistence agricultural production of women in Imo State, Nigeria. Livestock Res. Rural Dev., 18: 47-61.

Ojo, O., 2001. Yoruba women, cash crop production and the colonial State: 1920-1957. Proceedings of the 2001 Conference on Atlantic Crossings: Women's Voice, Women's Stories from the Caribbean and the Nigerian Hinterland, May 18-21, 2001, Dartmouth College, Hanover, New Hampshire, pp: 18-20.

Okoduwa, A.I., 2007. Where bottom dropped off manufacturing innovation in Nigeria: An example of the Esan people in Edo State. Stud. Tribes Tribals, 5: 29-34.

Ozoya, M.I., 2008. Rural women and household food security in Esan West local government area of Edo State, Nigeria. MSc Thesis, Covenant University, Ota, Nigeria.
Ozoya, M.I., C.T. Iruonagbe and P.A. Edewor, 2016a. The extent of disempowerment among Esan women farmers of Edo State, Nigeria. Proceedings of the international conference on communication, business and education, January 23-24, 2016, sports science institute of south africa, vancouver, canada, pp: 91-94.

Ozoya, M.I., P.A. Edewor, C.T. Iruonagbe and I.A. Chiazor, 2016b. Rural women's empowerment through education in Southern Nigeria: Implications for global. Proceedings of the International Conference on Communication, Business and Education, January 23-24, 2016, Sports Science Institute of South Africa, Vancouver, Canada, pp: $87-90$

Tayo, O.G., O.N. Chukwuedozie and M.I. Ozoya, 2016. Violence against young women in informal cross-border trading in South-West Nigeria: Implications for economic development and poverty reduction. Intl. J. Gender Dev. Issues, 2: 112-120. 